\title{
IMPORTANCE OF UTILIZATION OF OMEGA-3 FATTY ACIDS IN HUMAN AND ANIMAL NUTRITION
}

\author{
Lj. Sretenović, V. Pantelić, Ž. Novaković \\ Institute for Animal Husbandry, 11080, Belgrade-Zemun, Republic of Serbia \\ Corresponding author: sretenlj@gmail.com \\ Invited paper
}

\begin{abstract}
Life of modern people in urban conditions is characterized by lack of movement, which is main condition for maintenance of health, presence of large amount of additives and pesticide residua in food of plant and animal origin and polluted air and water. If the presence of oxidative stress is added as part of normal metabolism occurring during degradation of nutritive substances, when great quantity of free radicals is released, which organism in these conditions often is not capable of neutralizing, the homeostatic mechanisms are disturbed and this leads to health disturbances and even severe illnesses. In such complex living conditions, science is facing the challenge of finding out the way to prevent diseases and slow the aging process using food, primarily basic food stuffs - milk and meat, enriching them with certain substances which are of vital importance to our health. One of the ways is use of functional food which should contain not only its main nutritive value but also such ingredients which have impact on improvement of general health condition, i.e. they have preventive and therapy effect. In this paper, a review of the significance of omega-3 fatty acids in human nutrition is presented. As essential substances they cannot be synthesized in the organism, but have to be introduced through diet. Also, the significance of some essential omega- 6 fatty acids as well as their mutual relation, are presented. The role of omega-3 fatty acids in animal nutrition is also pointed out in this paper, introduced or consumed by animals either by grazing or as diet supplement, which influence improvement of their production, reproduction and health performances.
\end{abstract}

Key words: functional food, omega-3 fatty acids, omega- 6 fatty acids

\section{Introduction}

Modern way of life sets new demands in the field of human life style especially nutrition, in all its segments, from number of meals, type of food we use and especially its quality. 
The term "functional food" includes those food stuffs which beside their basic main nutritive value, contain non-essential substances with potential positive effects on body and mental health.

More precisely, this food should consist of functional food nutrients with certain specific properties, they are main part of every day nutrition and exclusively of natural origin, i.e. they cannot consist of tablets, capsules, solutions, powders, etc. It should contribute to improvement of body functions, increase of immunity, faster recovery from diseases, slowing of the aging process, etc. Functional food should contain ample functional food stuffs, adequate amounts of food should be consumed, food should be diverse and with uniform presence in nutrition (Sretenović et al., 2009). This concept was introduced in Japan in the eighties of the last century.

Examples of different food which is considered to be „functional food“" contains following active substances: food made of soya (isoflavons), cranberry juice (proanthocyanidins), red grapefruit juice (rasveratrol), tomato (likopene), green tea (katehin). Also, bioactive components in functional food can be increased or added to traditional food by methods of genetic engineering. Nice example is tomato with high content of likopene which has strong antioxidative properties or flax with increased content of omega -3 fatty acids.

Today, in the focus of scientific interest are two fatty acids which are polyunsaturated, omega-3 and omega- 6 fatty acids which are contained in certain food stuffs in so called traditional food or are added to food using different methods making it functional. Sources of omega-3 (linoleic acid) are: fish oil as rich source and it contains usually $30-50 \%$ omega- 3 fatty acids in relation to total weight, fish from Northern seas, and fish such as tuna, trout, salmon are especially rich sources of these acids, crabs, flax seed, green vegetables and legumes. Small amounts of omega-3 fatty acids are present in beef, pork and poultry meat. Regardless of the fact that they are present in small quantities in these meats, by consumption of large quantities of meat in diets in developed countries, the need for them is satisfied.

Sources of omega- 6 or linolenic acid are in meat and vegetables and plant oils (sunflower, soy, linen seed), milk, etc.

Unsaturated fatty acids decrease the level of cholesterol, which caused the general opinion that fatty acids should completely be replaced by unsaturated. This position was later revised, since poly-unsaturated fatty acids can have harmful effect if introduced in excessive amounts into organism and lead to decrease of immunity, carcinogenic effect, osteoporosis, holelitiasis, increased production of lipid peroxides and lowering of HDL cholesterol. Recommended daily intake of poly-unsaturated fats today is up to $10 \%(7-8 \%)$, and linoleic is $1 \mathrm{~g} /$ day. 
In this paper, the significance of omega- 3 will be reviewed as well as of omega- 6 fatty acids in products of animal origin, i.e. milk and meat and their role in preserve of health.

\section{Importance of Omega-3 fatty acids in human nutrition}

In regard to healthy food and its impact and influence on the quality and duration of life, it is not said without reason that person is old as his blood vessels are. It is proved that cardiac diseases and diseases of blood vessels, as well as incidence of arteriosclerosis are direct consequences of the introduction of food of animal origin with high amount of lipids, i.e. saturated fatty acids, especially certain forms of cholesterol which is main cause of disease.

Taking this into consideration, in recent years, programs of healthy food enriched with unsaturated fatty acids, primarily omega-3, since it was unambiguously proved that they are of essential importance for human health (Sretenović, 2005).

Interest in omega-3 fatty acids is related to studies carried out in Greenland in 1970. Bang et al.(1980) published that Eskimo population of the Western part of Greenland has exceptionally low rate of coronary diseases, and it was brought into relation with their nutrition traditionally rich in fish and different sea foods.

This type of food is rich in omega-3 fatty acids called eicosapentaenoic (EPA) and docosahexaenoic acid (DHA). Also other populations such as inhabitants of Alaska and Japan, with similar nutrition patterns had lowers rate of diseases of cardiovascular system.

Understanding of the role of omega-3 fatty acids in preservation of health starts with knowledge of the chemical structure of certain fatty acids. Omega-3 fatty acids are long chain poly-unsaturated fatty acids (LC-PUFAs) which include: alfa-linolenic acid (ALA) which is the most known omega-3 fatty acid in human nutrition. ALA has 3 double bonds on 3, 6, 9 atom of $\mathrm{CH} 3$ terminal end. Human body cannot synthesize ALA which makes it "essential fatty acid" which indicates that it is necessary to introduce it to organism through food. Long chain polyunsaturated fatty acids (LC-PUFAs) represent approx. $20 \%$ of brain dry matter and its deficit is critical for development and its function (Belz et al., 2007).

It is present mainly in plant oils such as walnut, legumes, vegetables, flax seed, some oils obtained from vegetables and cereals. Flax seed is the richest source of alfa-linolenic acid with presence of over $50 \%$ in total content of fatty acids. Fish, fish oil, and algae oils are the riches source of other two omega-3 fatty acids, which are EPA-20:5, and DHA-22:6.

Alfa-linolenic acid (ALA) in several degrees of change can be converted in body into EPA and DHA, but this amount is not significant (less then 5\%). In intake of omega- 3 and omega- 6 fatty acids into human organism, the mechanism of 
action is not quite known, but it is thought that linolenic (omega-3) competes with linoleic (omega-6) over enzyme delta desaturaze which converts them either into DHA and EPA or into arachidonic. If there is more arachidonic acid in cell membrane thromboxanes, prostacyclins and other substance are created which have harmful effect (they narrow blood vessels though vasoconstriction, increase thrombocyte aggregation, etc.). These three fatty acids are in cis configuration.

Omega-3 fatty acids have positive effect on heart health and potentially other diseases such as cancer, diabetes as well as neurological disorders. Persons in specific physiological conditions such as gravidity, lactation, adolescence, children, etc., have benefits from consumption of omega-3 fatty acids in adequate quantities. Necessity of the intake of omega-s fatty acids by pregnant women and women nursing must be pointed out, since it was unambiguously proved that they have influence on development of brain functions of the foetus and newborns.

Consumption of recommended amounts of omega-3 fatty acids can contribute to improvement of general health and welfare of entire population, especially young people.

Deficit in omega-3 fatty acids can result in neurological abnormalities and retardation in growth, weakness, reduced learning ability, disturbances in motor coordination, changes in behaviour, high level of triglycerides, high blood pressure, oedema, dry skin, mental retardation, immune disfunction, etc. All symptoms of deficit can disappear with the return of omega-3 into nutrition.

In order to overcome numerous health problems, the food stuffs which aren't traditional sources of omega- 3 fatty acids such as dairy products and pastry, meat, baby foods, etc. are enriched with moderate quantities of these fatty acids and there is increased demand for such products because of their well known positive effect on human health (Sretenović et al., 2007a).

Our diet consists among other things of combination of fats and oils whose main structural components are fatty acids. We consume approx. 20 different types of fatty acids which are categorized as saturated, mono-unsaturated and polyunsaturated fatty acids.

All diet fats are not utilized in the same way and fatty acids have different pathways and destinies in the organism, including beta oxidation for creation of energy, storing in depots for incorporation into phospholipids which represent main structural components of all cell membranes. Scope of incorporation into cell membranes depends on consumed quantity. Enriching of cell membrane with omega-3 can change the cell signal, function of cell proteins and expression of genes.

Since human organism has no enzymatic system necessary for synthesis of omega-3 fatty acids, they must be introduced through diet (they are called "essential fatty acids"). 
Modern biotechnologies offer different ways for enriching of products with omega-3 (Sretenović et al., 2007). Products of animal origin such as milk, meat and eggs, enriched with omega-3 fatty acids are obtained by inclusion of sources of these acids into animal diets. Increase of the content of omega- 3 fatty acids is achieved by application of modern biotechnological procedures in selection and plant breeding, by growing of varieties which synthesize higher quantity of ALA, i.e. fatty acids similar to EPA and DHA.

\section{Importance of omega-6 fatty acids in human nutrition}

The most important and present omega- 6 fatty acid is linoleic acid which is present in seed of sunflower, gourd, soy bean, walnut, sesame and flax. Longer deficiency of linoleic acid in diet is fatal. All symptoms of deficit can disappear with its inclusion into nutrition. Conjugated linoleic acid (CLA) is family of at least 13 isomers of linoleic acid and is mainly present in meat and dairy products.

As stated in the name, double bonds are conjugated. Conjugated fatty acids are polyunsaturated fatty acids in which at least one pair of double bonds is separated with one saturated (single) bond, like in case of conjugated linoleic acid, and not in case of methyl group (-CH2-) which separates double bonds in nonconjugated acids.

CLA - has 18 atoms and 2 double bonds, it is present in two isomersd in cis and trans form.

Antioxidative and anticancerogenic properties are attributed to CLA, and studies and results obtained on laboratory animals are very encouraging in prevention of breast, skin and colon tumours.

European team of researchers under leadership of Swiss scientist Rist et al. (2007) stated that by $50 \%$ more CLA was found in milk of mothers consuming milk and meat enriched with CLA, which is of great importance for the health of their children. Extremely important is to introduce through food sufficient amount of linoleic acid CLA since deficiency will be expressed in following symptoms: changes on skin similar to eczema, hair loss, liver degeneration, changes in behaviour, kidney degeneration, inclination to infections, wounds heal very slowly, loss of water through skin related to thurst, male sterility, abortions in women, changes similar to arthritis, heart and circulation disorders and slow growth.

Investigations relating to effects of conjugated linoleic acid in diets for humans indicate that it influences decrease of body fats, especially abdominal fat, improves the profile of serum lipids and reduces total flow of glucose (Blankson et al., 2000). Maximum reduction of body fats is achieved with daily dosage of $3.4 \mathrm{~g}$. However, it was established that addition of CLA leads to increase of the level of C-reactive proteins which possibly induce oxidative stress (Yoneyama et al., 2007). 
Although complexity of the action of CLA in organism is still not completely discovered, it is widely accepted among scientists that CLA in certain way presents balance to negative effects of linoleic acid and in most recent researches it is recognized as substance of great importance for regulation of lipid and protein metabolism and therefore it is also called "growth factor". When it was included into diet it induced increase of muscle mass and at the same time reduction of body fats, i.e. it induced growth through increased efficiency of food (Risérus et al., 2003).

Stated facts unambiguously indicate that functional food, primarily meat and milk enriched with mentioned bio-active supplements, will become irreplaceable part of every day diets.

\section{Omega-3 and Omega-6 fatty acid ratio}

Beside the absolute content of omega- 3 fatty acids in diet, very important is also relation between omega-3 and other types of unsaturated fatty acids, these are omega- 6 fatty acids, in diet, and it is vital factor for health and longevity (Simopoulos, 1999). Contrary to cell proteins whose synthesis is genetically determined, composition of polyunsaturated fatty acids which are present in cell membranes greatly depends on composition of diets. There are several types of fats/lipids present in diet. Some of the most crucial fats represent components of cell walls of all cells in the organism. After detailed study of these fats it was established that the ratio of omega-3 and omega- 6 fatty acids higher than 4:1induces numerous health problems. This is especially important because in case of cattle fed concentrated food, ratio of these two acids in diet is over 20:1, whereas in case of cattle on pasture it is 3:1. Similar ratio of these two acids is established in animal products, when concentrated type of diet is compared to grazing. Products obtained from cattle on pasture are rich in fats which contribute to health improvement and have low content of fats which are related to diseases. If we turn our attention to situation in the past, situation was following: by analysis of food in Paleolithic period we obtained results showing that diet consisted of small amounts of fat with almost identical quantities of omega- 3 and omega- 6 fatty acids. In the last 100 years rapid changes in diets occurred. Modern oil processing industry based on processing of oleaceous plants rich in omega- 6 fatty acids developed very quickly. Modern agriculture, for the purpose of generating of higher profit realized through high yields and shorter fattening period, started to increase the production of concentrated grain food rich in omega- 6 fatty acids used in livestock nutrition. Also, aggressive industrialized management in agriculture imposed such techniques which lead to decrease of omega-3 fatty acids in human nutrition: green vegetables, meat, eggs and even fish. Disturbed ratio of omega- 6 and omega-3 fatty acids is noticeable on example of wild edible plants and wild 
animals and birds with products of modern agriculture. Products of modern agriculture often have drastically lower level of omega-3 fatty acids. It was established that expansion of the ratio of omega- 6 and omega- 3 fatty acids of $1: 1$ is man induced in animal and plant sources and it is estimated that today, the ratio of omega- 6 and omega- 3 in plant sources is 10:1. Modern diet consisting of meat, fish, poultry and plant oils has ratio of 20 or 25:1. Omega-3 fatty acids present in green leaves of plants are essential for photosynthesis. When animals graze they naturally accumulate these essential fats in their body. For instance, beef steak from cattle grazing contains 2 to 6 times more omega- 3 fatty acids compared to steak from cattle fed concentrated food.

Increased quantities of omega- 6 polyunsaturated fatty acid and high value of the ratio omega-6/omega- 3 is connected to pathogenesis of numerous diseases, including cardiovascular disease, cancer, inflammatory and auto-immune diseases. In diets of modern civilization ratio of omega- 6 and omega- 3 fatty acids in practice is $15: 1$, whereas the ratio $2: 1$ to $4: 1$ is related to reduced mortality caused by cardiovascular diseases, reduced inflammatory process in rheumatoid arthritis and reduced risk of breast cancer. Some researchers (Harris et al., 2006) think that this ratio should not be observed so strictly in sense of the benefit from such nutrition, and that it would be better to increase the intake of omega- 3 fatty acids than to reduce the intake of omega- 6 fatty acids, because reduced intake of polyunsaturated fatty acids induces cardiovascular diseases.

It is important to point out that ratio of omega- 6 and omega- 3 fatty acids is extremely important, since these two substances act jointly in preservation of health. Omega-3 influences reduction of inflammatory processed whereas omega- 6 (other essential fatty acids) contributes to increase and spreading of inflammatory processes. Inadequate ratio of these two essential fatty acids contributes to development of diseases, whereas adequate balance of these two acids contributes to maintaining and even improvement of health. Healthy diet should contain 2 to 4 times more omega- 6 fatty acids then omega-3. Typical diet of Americans and entire Western world contains 14-25 times more omega- 6 fatty acids than omega-3, which explains numerous health problems in these countries.

Contrary to that, Mediterranean diet contains much healthier ratio of omega- 3 and omega- 6 fatty acids and many researches indicated that people who consume this kind of food have suffer less of heart diseases. These diets contain additional fatty acid, omega-9 to which the incidence of cancer and heart diseases is attributed. Mediterranean diet doesn't include high quantities of meat (which is rich in omega- 6 fatty acids) and includes food rich in omega- 3 fatty acids, such as cereal grain, fresh fruits and vegetables, olive oil, fish, garlic and moderate consumption of wine. 


\section{Importance of Omega-3 fatty acids in animal nutrition}

We often hear expression "We are what we eat". However, true expression would be we are what our animals eat. Products obtained from animals on pasture offer not only omega-3 fatty acids. They contain significant quantities of two "good" fats, monounsaturated oils and stearic acid, but not trans fatty acids which were man made and obtained by processing. They are also the richest known sources of CLA (conjugated linolenic acid) and contain high amounts of vitamin $\mathrm{E}$ and beta carotin. Conjugated linolenic acid can exclusively be found in animal products. Good source of CLA are beef and mutton, especially those heads of cattle and sheep on pasture since they contain significantly higher quantity of CLA compared to animals fed concentrated food. Meat and milk products of animals on pasture can contain 300-500\% more CLA compared to cattle fed diets consisting of $50 \%$ of hay and silage and 50\% concentrated feed (Dhiman, 2001). In general, forage food contains higher concentration (18:3) of linolenic acid, whereas linoleic $18: 2$ is contained mainly in cereals and seeds.

Since milk and dairy products are rich in CLA, by their consumption therapy effects are achieved in regard to health. Therefore, there is sufficient justification for milk and dairy products to be present in our every day meal.

Finally, meat obtained from animals reared on pastures compared to those fed concentrated food has lower content of total fat and calories which makes it ideal for nutrition of modern consumers who spend most of the time sitting down. Meat deriving from animals who grazed has significant amount of vitamin $E$ which has important role in maintenance of meat, because of well known antioxidative effect of this vitamin. Content of vitamin $\mathrm{E}$ in grass is 20 times higher compared to soy bean or maize. This is reason why meat deriving from traditionally known regions where cattle is on pasture, are so valued and in demand (Sretenović et al., 2008).

In regard to enriching of milk and meat with sources of omega-3 fatty acids, very interesting is research carried out by Oba et al. (2008). They obtained very important results by comparing the effects of $\alpha$-linolenic acid in milk fat from Holstein cows which were fed diets supplemented by whole unprocessed, ground flax seed in the amount of $100 \mathrm{~g}$ per $\mathrm{kg}$ of dry matter of diet. Problem occurs because of the specificity of digestion in ruminants where bio-dehydrogenization of unsaturated omega-3 fatty acids occurs, and in this way their digestibility is decreased unless they are made available, by processing procedure, to microorganisms of rumen. Hypothesis that both feeding treatments influence the increase of concentration of $\alpha$-linolenic acid in milk fat $\left(8.3\right.$ and $\left.8.6 \mathrm{~g} / \mathrm{kg}^{-1}\right)$ was confirmed and its concentration was three times higher in comparison to the one before the treatment, where instead of flax seed sunflower seed was used $\left(2.6 \mathrm{~g} / \mathrm{kg}^{-}\right.$

$\left.{ }^{1}\right)$. Both treatments with whole unprocessed flax seed and ground seed indicate 
similar degree of absorption of $\alpha$-linolenic acid in spite of lower digestibility of the whole unprocessed seed, which is noticeable by its content in faeces $(259 \mathrm{vs} .129 \mathrm{~g}$ day $\left.^{-1} ; P<0.001\right)$. Ground flax seed doesn't increase significantly the absorption of $\alpha$-linolenic acid in milk fat, since by increasing of its digestibility also the level of bio-dehydrogenization in rumen is increased.

Also, in research of Petit (2002) the effects of whole unprocessed flax seed as source of omega-3 fatty acids in diets for high yielding cows were studied and compared to other energy sources such as Megalac and micronized soy bean as energy source. It was concluded that inclusion of whole flax seed into diets for cows influenced not only the increase of quantity of milk $(35.7 \mathrm{~kg} /$ day compared to other two energy sources -33.5 and $34.4 \mathrm{~kg} /$ day), but also the protein content in milk as well as decrease of ratio of omega- 6 and omega- 3 fatty acids, which made it product of high quality from the aspect of human nutrition.

Additional aspect of importance is global warming. This problem is caused not only by humans but also cows. Scientists claim that methane released by cows is significant source of gas of the green house effect, and they working on the way to solve this and reduce the methane release. Bacteria in digestive tract of cows produce methane which is the second important gas (beside carbon dioxide) which effect global warming. Since methane is considerably less present in atmosphere compared to carbon dioxide, it is often neglected that this gas 20 times more efficiently warms the atmosphere compared to carbon dioxide. Cattle can produce from 250 to 500 lit. methane per day. Scientists are attempting to find different tactics including breeding and genetic engineering and various adjustments of bacteria in digestive tract, which would decrease the methane release. So production of methane is decreased by $18 \%$ when in concentrated diets consisting of grain alfalfa and flax seed were included. Quantity of milk remained the same. Scientists claim that cows were used to grazing for millions of years on grass rich in omega-3 fatty acids which contribute to the activity of their digestive tract. But with the use of soy bean and maize which are used in fattening of cattle, the structure of fatty acids is changed and this contributes to increased production of methane (Johnson and Johnson, 1995).

\section{Acknowledgment}

Research was financed by the Ministry of Science and Technological Development, Republic of Serbia, project TR 20042. 


\title{
Značaj korišćenja omega-3 masnih kiselina u ishrani ljudi i životinja
}

\author{
Lj. Sretenović, V. Pantelić, Ž. Novaković
}

\section{Rezime}

Život savremenog čoveka u urbanim uslovima karakteriše nekretanje kao osnovni uslov zdravlja, prisustvo velike količine aditiva i rezidua pesticida u hrani biljnog i animalnog porekla, zagađeni vazduh i voda. Ako se tome doda i prisustvo oksidativnog stresa kao deo normalnog metabolizma koji se dešava pri razlaganju hranljivih materija, pri čemu se oslobodi velika količina slobodnih radikala, koje organizam u ovakvim uslovima često nije sposoban da potpuno neutrališe, dolazi do narušavanja homeostatskih mehanizama koje često dovode do narušavanja zdravlja pa i do najtežih bolesti. U ovakvim složenim uslovima življenja, izazov nauke je da pronađe načine kako da putem hrane, pre svega osnovnih životnih namirnica mleka i mesa, obogaćujući ih pojedinim materijama koji su od vitalnog značaja za naše zdravlje, utiče na sprečavanje bolesti i usporavanje procesa starenja.

Jedan od načina je i korišćenje funkcionalne hrane koja pored osnovne hranljive vrednosti treba da sadrži i takve sastojke koji utiču na popravljanje opšteg zdravstvenog stanja, odnosno deluju preventivno i terapeutski.

U radu je na revijalan način predstavljen značaj omega-3 masnih kiselina $u$ ishrani ljudi koje kao esencijalne materije ne mogu da se sintetišu u organizmu, već moraju da se unesu putem obroka. Takođe, ukazano je i na značaj pojedinih esencijalnih omega-6 masnih kiselina kao i međusoban odnos ovih dveju kiselina. Pored toga, istaknuta je uloga omega-3 masnih kiselina u ishrani životinja koje ih unose ili putem paše ili kao dodatak obroku, a one utiču na popravljanje njihovih proizvodnih, reproduktivnih i zdravstvenih performansi.

\section{References}

BELTZ B.S., TLUSTY M.F., BENTON J.L., SANDEMAN D.C. (2007): Omega-3 fatty acids upregulate adult neurogenesis. Neuroscience Letters., 415, 154-158.

BANG H.O., DYERBERG J., SINCLAIR H.M. (1980): The composition of the Eskimo food in northwestern Greenland. Am J Clin Nutr., 33, 2657-2661.

BLANKSON H., STAKKESTAD J.A., FAGERTUN H., THOM E., WADSTEIN J., GUDMUNDSEN O. (2000): "Conjugated linoleic acid reduces body fat mass in overweight and obese humans". Journal of Nutrition, 130, 12, 2943-2948. 
DHIMAN R.T. (2001): Role of diet on conjugated linoleic acid content of milk and meat, Journal of Animal Science, 79, 168-172.

HARRIS W.S., ASSAAD B., POSTON W.C. (2006): Tissue omega-6/omega-3 fatty acid ratio and risk for coronary artery disease. Am J Cardiol., 21, 98, 4A, 19i-26i.

RIST L., MUELLER A., BARTHEL C., SNIJDERS B., JANSEN M., SIMOESWUST A.P., HUBER M., KUMMELING I., VON MANDACH U., STEINHART H., THIJS C. (2007): "Influence of organic diet on the amount of conjugated linoleic acids in breast milk". British Journal of Nutrition.

JOHNSON K.A., JOHNSON D.E. (1995): Journal of Animal Science, 73, 8, 2483-2492. OBA M., THANGAVELU G., DEHGHAN-BANADAKU M., AMBROSE J.D. (2008): Unprocessed whole flaxseed is as effective as dry-rolled flaxseed at increasing $\alpha$-linolenic acid concentration in milk of dairy cows. Livestock Science. PETIT H.V. (2002): Journal od Dairy Science, 85, 6, 1482-1490.

RISÉRUS U., SMEDMAN A., BASU S., VESSBY B. (2003). "CLA and body weight regulation in humans". Lipids 38, 2, 133-137.

SIMOPOULOS A.P., ROBINSON J. (1999): The Omega Diet. The Lifesaving Nutritional Program Based on the Diet of the Island of Crete. New York, HarperCollins.

SRETENOVIĆ LJ. (2005): Dobijanje mleka sa osobinama funkcionalne hrane putem ishrane mlečnih krava. XI Međunarodni simpozijum tehnologije hrane za životinje »Obezbeđenje kvaliteta«, Vrnjačka Banja 30. maj-3. jun, 149-157.

SRETENOVIĆ LJ., ALEKSIĆ S., PETROVIĆ M.M., PETROVIĆ M.P., STOJANOVIĆ LJ. (2007): Application of modern technology of nutrition in high yielding cows in dry period and early lactation. Biotechnology in Animal Husbandry, 29-40.

SRETENOVIĆ LJ., ALEKSIĆ S., PETROVIĆ M.P., MIŠČEVIĆ B. (2007a): Nutritional factors influensing improved milk and meat quality as well as productive and reproductive parameters of cattle. Biotechnology in Animal Husbandry, 23, 5-6, Book 1, 217-226.

SRETENOVIĆ LJ., PETROVIĆ P.M., ALEKSIĆ S., PANTELIĆ V., KATIĆ V., BOGDANOVIĆ V., BESKOROVAJNI R. (2008): The influence of yeast, probiotics and enzymes in rations on transition dairy cows performances Biotechnology in Animal Husbandry, 24, 5-6, 33-43.

SRETENOVIĆ LJ., ALEKSIĆ S., PETROVIĆ M.M., PANTELIĆ V., BESKOROVAJNI R., RUŽIĆ D., ĐEDOVIĆ R. (2009): Dobijanje mesa i mleka sa osobinama funkcionalne hrane. Zbornik naučnih radnika, Institut "PKB Agroekonomik", 67-78

YONEYAMA S., MIURA K., SASAKI S., YOSHITA K., MORIKAWA Y., ISHIZAKI M., KIDO T., NARUSE Y., NAKAGAWA H. (2007): Dietary intake of fatty acids and serum C-reactive protein in Japanese. Journao of Epidemiology, 17, 3, 86-92. 